ROCZNIKI TEOLOGICZNE

Tom LXVI, zeszyt $10-2019$

DOI: http://dx.doi.org/10.18290/rt.2019.66.10-3

LIDIA ŁYSIUK

\title{
PSYCHOLOGICZNE UWARUNKOWANIA WYCHOWANIA MORALNEGO DZIECI W MŁODSZYM WIEKU SZKOLNYM
}

\section{PSYCHOLOGICAL DETERMINANTS OF CHILDREN MORAL EDUCATION AT PRIMARY SCHOOL AGE}

\begin{abstract}
A b s t r a c t. The aim of the article is to systematize theoretical and empirical data concerning psychological determinants of children moral education at primary school age. It is assumed that morality appears in situations when one should take into account needs and rights of another person and acts as a system of self-regulation to choose between morally desirable behavior and behavior beyond moral norm. Each stage of child's development has been characterized by specific social interactions, determined formation of certain structures of moral self-regulation. New school life conditions cause deepening of moral reality learning and influence moral identity development. According to the mentioned features of morality development, substantive aspects of the overall process of upbringing at a primary school age were identified. First of all, impacts directed at the separate elements of moral self-regulation system formation (moral knowledge, moral identity, moral assessments, empathy and others). Second, czostajategory of interactions refers to real situations when child is a subject or object of moral activities. Features of moral situation determine educational goals and system of influences aimed at supporting children's morality development.
\end{abstract}

Key words: morality; morality development; primary school age; moral education.

Dr hab. Lidia Łysıuk - Wyższa Szkoła Ekonomii i Innowacji w Lublinie, adres do korespondencji: ul. Projektowa 4, 20-209 Lublin; e-mail: 1lysiuk@gmail.com 


\section{WPROWADZENIE W PROBLEMATYKE}

Najczęściej wychowanie ku moralności określamy jako proces przekazania norm i zasad, za pomocą których dzieci i młodzież potrafią rozpoznać moralne wymiary różnorodnych sytuacji oraz postępować według przekazanych norm. Większość nauczycieli i rodziców zdaje sobie sprawę z konieczności rozwoju moralności, ale wobec dzieci w młodszym wieku szkolnym skupiają się raczej na kształceniu wiedzy i umiejętności z zakresu przedmiotów szkolnych. Postępy w uczeniu się mają dla nich najważniejsze znaczenie, ponieważ wskazują na sukcesy wychowawcze. Tutaj prawie wszystko jest widoczne: kryteria sprawdzania i oceniania są jasno określone. Proces uczenia się dziecka jest dość sformalizowany i kontrolowany, metody nauczania są mniej więcej oczywiste. Ocenić postępy w rozwoju dziecka w sferze moralności jest bardzo trudno, ponieważ obserwowane zachowanie, nawet odpowiadające normom, nie zawsze świadczy o prawdziwej moralności. Wewnętrzna strona moralności czy psychiczne struktury i mechanizmy odpowiadające za zachowanie moralne zwykle są „ukryte” dla innych ludzi. Oprócz tego, sytuacje o moralnym znaczeniu nie pojawiają się systematycznie, lecz raczej sporadycznie i w sposób niezaplanowany. W tych niezwykłych sytuacjach nauczyciele oraz rodzice często nie wiedzą, w jaki sposób reagować, i odczuwają zakłopotanie, niepokój, złość, ale właśnie podobne sytuacje stanowią warunki konieczne do kształcenia moralnej regulacji zachowania. Celem niniejszego artykułu jest usystematyzowanie teoretycznych i empirycznych danych, dotyczących psychologicznych uwarunkowań wychowania moralnego dzieci w młodszym wieku szkolnym.

\section{MORALNOŚĆ JAKO IDEALNA FORMA REGULACJI ZACHOWANIA CZŁOWIEKA}

Punktem wyjściowym do rozważań o wychowaniu dziecka ku moralności stała się idea L. Wygotskiego, mówiąca, że rozwój dziecka odbywa się poprzez interakcje ze środowiskiem, gdzie skończona forma idealna, która powinna być osiągnięta, istnieje w środowisku, wchodzi w interakcje i wpływa na dziecko ${ }^{1}$. Idealna forma opisująca rzeczywistość moralną jest przedmiotem rozważań filozoficznych, do których zwracają się prawie wszyscy badacze rozwoju moralnego. Jak stwierdza M. Chutorański, kognitywne teorie rozwoju moralnego J. Piageta, L. Kohlberga zostały zaczerpnięte z koncepcji Kanta i Kartezjusza.

\footnotetext{
L.S. Wygotsky, Sobranie Socinenii, t. IV, Moskwa: Wydawnictwo Pedagogika 1984.
} 
Teoria zaś i badania M. Hoffmana, poświęcone empatii, jako poważnej części moralności człowieka, wynikają z koncepcji D. Hume’a i A. Smitha². Podłożem behawioryzmu, nakierowanym na badanie zachowania moralnego, stał się filozoficzny prąd pragmatyzmu W. Jamesa ${ }^{3}$.

Charakterystyka idealnej formy czy modelu moralności, oprócz wskazania na jej istotne elementy, potrzebuje także wyjaśnienia, jak ona funkcjonuje, oraz jaką funkcję spełnia w życiu człowieka i społeczeństwa. Podstawowe założenia teorii wybitnego etyka O. Drobnickiego pozwalają nam pogłębić zrozumienie moralności. Jego zdaniem moralność jest jedną z form regulacji zachowania człowieka za pomocą norm. Normy społeczne okazują się konieczne, gdy osobiste intencje człowieka wchodzą w sprzeczność z potrzebami innego człowieka lub otoczenia społecznego ${ }^{4}$. O. Drobnicki wyróżniał normy instytucjonalne i normy nieinstytucjonalne. Normy instytucjonalne są obowiązkowe do stosowania w relacjach międzyludzkich. Podmiotem tych norm są instytucje społeczne, które je opracowują i kontrolują ich wykonywanie. Grupy społeczne oraz każdy człowiek jest przedmiotem, do którego te normy są skierowane. Normy nieinstytucjonalne to formy zachowania, które zostały uznane przez zbiorowość za społecznie doniosłe i obowiązujące dla wszystkich. Do nich odnoszą się tradycje i obyczaje (na przykład normy grzecznościowe). Normy moralne odzwierciedlają poglądy odnośnie do tego, co stanowi dobro i zło, oraz określają, jakie zachowania są właściwe, a jakie godne potępienia. W odróżnieniu od innych norm wykonawca norm moralnych jest jednocześnie ich podmiotem i przedmiotem ${ }^{5}$. W sytuacjach moralnego wyboru człowiek spotyka się z koniecznością dokonywania wyboru między dwoma pragnieniami, które wykluczają się wzajemnie (np. nie jest możliwe jednocześnie mówić prawdę i kłamać). Specyfiką moralnego wyboru jest to, że człowiek podejmuje decyzję bez jakiejkolwiek presji z zewnątrz, samodzielnie i swobodnie, na podstawie moralnej oceny sprzecznych intencji i czynności. Wykonywanie czynności, która odpowiada rozumieniu dobra, wywołuje poczucie dumy, natomiast działanie, które sam człowiek ocenia jako przekraczające normy moralne, doprowadza do przeżycia winy oraz wyrzutów sumienia.

Warto wskazać także na treść moralności. Wiadomo, że nakazy i zakazy moralne odzwierciedlają uniwersalne prawa życia ludzkiego, które zabezpieczają

2 M. Chutorański, Moralność, rozwój moralny, wychowanie moralne, „Teraźniejszość Człowiek - Edukacja” 2012, nr 2, s. 97-106.

${ }^{3}$ W. JAMES, Pragmatyzm. Nowoje nazwanie dla niekotorych starych metodow myszlenia. Popularnyie lekcii po filosofi, Moskwa: Wydawnictwo ЛКИ 2011.

${ }^{4}$ O.G. Drobnicki, Poniatie morali, Moskwa: Wydawnictwo Nauka 1974.

5 Tamże. 
istnienie i rozwój każdego człowieka oraz całego społeczeństwa. Człowiek nie potrafi osiągnąc szczęścia bez postępowania według tych norm i zasad. Wśród najbardziej znaczących moralnych wartości są miłość, poszanowanie życia i godności człowieka, sprawiedliwość, prawdomówność, szczodrość, uczciwość.

Reasumując, można stwierdzić, że moralność jest istotnym wymiarem stosunków międzyludzkich i ujawnia się w sytuacjach, gdy należy uwzględniać potrzeby i prawa drugiego człowieka (wrażliwość moralna), a także wykonać czynność zgodnie z normą moralną, odpowiednią dla danej sytuacji. Dojrzała moralność jest skomplikowanym systemem samoregulacji, który występuje w sytuacjach konieczności samodzielnego dokonywania wyboru oraz który składa się z wiedzy o rzeczywistości moralnej (treść i sposób poznania), tożsamości moralnej, moralnych uczuć (wina, sumienie), woli (kierowanie swoim zachowaniem zgodnie z wewnętrznymi standardami) i empatii.

\section{ROZWÓJ MORALNOŚCI W MŁODSZYM WIEKU SZKOLNYM}

Psychologiczne struktury odpowiadające za moralność człowieka rozwijają się, poczynając od okresu niemowlęcego. Każdy etap rozwoju dziecka charakteryzuje się specyficznymi społecznymi interakcjami, które warunkują kształtowanie pewnych struktur samoregulacji moralnej.

Wchodzenie dziecka w środowisko szkolne rozszerza kontekst społeczny jego życia. Pojawiają się inne środowiska pozarodzinne, które stwarzają nowe wyzwania i szanse rozwoju moralnego. Nauczyciel staje się postacią bardzo ważną i może konkurować nawet z rodzicami. To powoduje utożsamienie dziecka z nim w stosunku do różnorakich aspektów życia szkolnego i przede wszystkim w stosunku do innych dzieci oraz ich zachowania. Jednocześnie należy pamiętać, że dziecko jest nosicielem moralnych wartości jego rodziny, które mogą wchodzić w konflikt z kryteriami dobra i zła nauczyciela.

Jeszcze jednym aspektem środowiska szkolnego jest wprowadzanie w życie dziecka norm, które są obowiązkowe dla wszystkich uczniów i którym trzeba podporządkować się nawet wtedy, kiedy dziecko nie chce się temu podporządkować. Zachowanie dziecka według norm oraz jego sukcesy i niepowodzenia szkolne okazują się niemal nieustannie oceniane przez dorosłych i rówieśników. Te dość skomplikowane warunki związane bezpośrednio z uczeniem się mają duży potencjał rozwoju mechanizmów samoregulacji, ale oczywiście w tej przestrzeni pojawiają się także kolizje o charakterze moralnym. Najbardziej znanymi są sytuacje, kiedy dzieci otrzymują niskie oceny oraz zostają nieprzygotowane 
do lekcji i w celu uniknięcia różnego rodzaju nieprzyjemnych konsekwencji zaczynają kłamać ${ }^{6}$.

$\mathrm{W}$ młodszym wieku szkolnym relacje $\mathrm{z}$ rówieśnikami stają się ważnym czynnikiem rozwoju moralności. Dzieci w szkole z konieczności wchodzą w interakcje między sobą, ale często ich relacje nie mogą być poddane kontroli ze strony dorosłych. Dziecko więc znajduje się w sytuacji, gdy musi samodzielnie dokonywać wyboru między intencją zachowywania się według norm rodzinnych a dążeniem do przynależności i akceptacji ze strony rówieśników, wyboru między autorytetem dorosłych a przyjaciółmi.

Nowe warunki zwiększają nie tylko liczbę kontaktów, ale i prowadzą do częstej konfrontacji własnych potrzeb i oczekiwań dziecka z potrzebami, celami i planami innych ludzi (nauczyciele, rodzice, rówieśnicy). Rzeczywistość moralna staje się bardziej skomplikowana i ujawnia się to w narastaniu różnorodności sytuacji, czynników, wymagających moralnej regulacji oraz w pojawieniu się sytuacji, w których należy dokonywać wyboru między dwiema moralnymi normami ${ }^{7}$.

Poszukiwanie informacji, dotyczącej psychologicznych mechanizmów regulacji zachowania według norm moralnych w młodszym wieku szkolnym, wykazało dość małą liczbę badań na ten temat. Wśród nich dominują te, które zostały przeprowadzone w ramach podejścia kognitywnego (J. Piaget, L. Kohlberg, E. Turiel, J. Smetana i in.)

Ważnym elementem mechanizmu moralnej regulacji jest tożsamość moralna, której rozwój zaczyna się w wieku przedszkolnym ${ }^{8}$. Istnieją badania o jej rozwoju w okresie adolescencji. Można się spodziewać, że pojawią się empiryczne badania poświęcone wyjaśnieniu właściwości kształtowania moralnego obrazu „ja” w młodszym wieku szkolnym. Jednocześnie trzeba uwzględnić dane odnośnie do zmian zachodzących w tym wieku w samoświadomości dzieci, które bez wątpienia warunkują rozwój moralny ${ }^{9}$. Po pierwsze, zwiększa się liczba cech obrazu ,ja” i wśród nich mnożą się właściwości interpersonalne, pojawiają się

${ }^{6}$ L.I. Borzowicz, Problemy formirowanija licznosti, Moskwa: Wydawnictwo Instituta prakticzeskoj psychologii 1997.

${ }^{7}$ M. Jambon, J. Smetana, Moral Complexity in Middle Childhood: Children's Evaluations of Necessary Harm, „Developmental Psychology” 50(2014), nr 1, s. 22-33.

${ }^{8}$ G. Kochanska, J.L. Koenig, R.A. Barry, K. Sanghang, J.E. Yoon, Children's Conscience during Toddler and Preschool Years, Moral Self, and a Competent, Adaptive Developmental Trajectory, „Developmental Psychology” 2010, nr 46, s. 1320-1332.

S. Harter, Developmental Processes in the Construction of the Self, w: Integrative Processes and Socialization: Early to Middle Childhood, eds: T.D. Yawkey, J.E. Johnson, Hillsdale, NJ: Lawrence Erlbaum Associates 1988, s. 45-78. 
także cechy i standardy moralne ${ }^{10}$. Po drugie, rozwój uczenia się sprzyja kształceniu umiejętności samooceniania i samokontroli wykonywania zadań z różnych przedmiotów szkolnych ${ }^{11}$. Zapotrzebowania i normy dotyczące aktywności dziecka uwewnętrzniają się i zaczynają pełnić funkcję wzorów, do których dziecko chce się dostosować. Utożsamianie się z tymi wzorami prowadzi do pojawienia się „ja” idealnego ${ }^{12}$, które zawiera obraz tego, jakim dziecko chce być, i staje się źródłem dążenia do samodoskonalenia, ale empiryczne badania moralnego „ja” idealnego zostały przeprowadzone tylko odnośnie do adolescentów ${ }^{13}$. Po trzecie, dzieci stają się świadome, że mają nie tylko pozytywne cechy, ale wyodrębniają także właściwości negatywne, co ujawnia się w rozwoju samooceny krytycznej i bardziej adekwatnego sposobu traktowania siebie ${ }^{14}$.

Przeprowadzona krótka analiza rozwoju moralnego w młodszym wieku szkolnym pozwoliła zebrać niektóre elementy tego procesu. Każdy z elementów stanowi fundament do wyznaczenia kierunków i sposobów wychowania ku moralności.

\section{PSYCHOLOGICZNE PODEJŚCIA DO WYCHOWANIA MORALNEGO W MŁODSZYM WIEKU SZKOLNYM}

Autorzy, którzy zajmują się problemami wychowania moralnego, ustalili, że nawet w specjalistycznym czasopiśmie („Journal of Moral Education”) brakuje prac dotyczących moralnego wychowania dzieci w młodszym wieku szkolnym ${ }^{15}$. Psychologowie, którzy są autorytetami w dziedzinie rozwoju moralnego, stwierdzają, że „nie ma postępu w łączeniu badań nad rozwojem moralnym z praktyką edukacji moralnej" ${ }^{16}$. Być może te wypowiedzi brzmią dość pesymistycznie, ale samo uznanie istniejących problemów pobudza do poszukiwania sposobów ich

${ }^{10}$ S. Harter, The Construction of the Self: Developmental and Sociocultural Foundations, New York-London: Guilford 2012.

11 W.W. Dawydow, Problemy razwiwajuszego obuczenia, Moskwa: Wydawnictwo Pedagogika 1986.

12 P. Burns, Razwitie Ja-koncepcji i wospitanie, Moskwa: Wydawnictwo Progress 1986. S. Harter, The Construction of the Self.

${ }^{13}$ S. Hardy, L.J. Walker, J.A. Olsen, R.D. Woodbury, J.R. Hickman, Moral Identity as Moral Ideal Self: Links to Adolescent Outcomes, „Developmental Psychology” 50(2014), nr 1, s. 45-57.

${ }^{14}$ S. Harter, The Construction of the Self.

${ }^{15}$ Chi-M. Leen, M.J. Taylor, Moral Education Trends over 40 Years: A Content Analysis of the Journal of Moral Education (1971-2011), „Journal of Moral Education” 42(2013), nr 4, s. 399-429.

${ }^{16}$ L. Nucci, E. Turiel, Capturing the Complexity of Moral Development and Education, „Mind, Brain and Education” 3(2009), nr 3, s. 151. 
rozwiązania. Zgodnie z przedstawionymi właściwościami rozwoju moralności spróbujmy wyodrębnić merytoryczne aspekty całościowego procesu wychowania w młodszym wieku szkolnym.

Podłożem wychowania moralności w rozpatrywanym okresie, podobnie jak i w innych okresach wiekowych, jest tworzenie atmosfery moralnej nie tylko w rodzinie, lecz także w szkole ${ }^{17}$. Wiadomo bowiem, że wrażliwość dorosłych (rodziców i nauczycieli) na moralne wymiary relacji oraz ich zachowanie stają się ważnymi czynnikami wychowania moralności ${ }^{18}$.

Życzliwe i wspierające relacje w szkole rozwijają u dziecka zaufanie, poczut cie bezpieczeństwa do nowego środowiska oraz gotowość dostosowania się do wartości i norm, których nosicielem jest nauczyciel. Odwrotnie, rygorystyczne wymagania, chłód emocjonalny, dystans, agresja ze strony nauczyciela wywołują u uczniów niepokój, gotowość do obrony, lęki, wykluczenie z życia szkolnego, prowadzą dzieci w świat niedokształconej moralności. Gdy nauczyciel rozumie znaczenie atmosfery szkolnej dla rozwoju moralności dzieci, to staje się wtedy świadomy, że odpowiada nie tylko za ich nauczanie. W związku z tym kształcenie kompetencji moralnych nauczycieli staje się konieczną oraz merytoryczną częścią ich przygotowania do pracy z dziećmi ${ }^{19}$.

Mając na uwadze naturę moralności, staje się jasne, że oprócz tworzenia w szkole moralnej atmosfery są potrzebne także zamierzone oddziaływania wychowawcze, nakierowane na wywołanie pewnych struktur psychicznych, o których zostało powiedziane wyżej.

Kształcenie wiedzy o normach $i$ zasadach moralnych najbardziej przyciaga uwagę specjalistów i wychowawców. Często dorośli przekazują dzieciom tę wiedzę bezpośrednio za pomocą słów w postaci nakazów i zakazów zamiast pobudzenia rozwoju umiejętności poznania rzeczywistości moralnej. Poznanie zaczyna się od zauważania moralnych wymiarów relacji międzyludzkich, które ujawniają się w zachowaniu innych ludzi: rówieśnicy, rodzeństwo, dorośli, bohaterzy z książek i filmów. Rodzice i nauczyciele powinni zwracać uwagę dzieci zarówno na niepożądane zachowanie moralne, jak i na pożądane, które

17 T. Dawson, Moral Education: A Review of Constructivist Theory and Research, unpublished position paper, Berkeley, CA: University of California at Berkeley 1994, https://www.researchgate. net/publication/254789360 (dostęp: 28.02.2018); C. FoA, D. Brugman and T. Mancinia, School Moral Atmosphere and Normative Orientation to Explain Aggressive and Transgressive Behaviours at Secondary School, „Journal of Moral Education” 41(2012), nr 1, s. 1-22.

18 D. Lapsley, P. Stey, Moral Self-Identity as the Aim of Education, w: Handbook of Moral and Character Education, red. L. Nucci and D. Narvaez, London: Taylor \& Francis 2014, s. 84-100.

19 G.D. Fenstermacher, R.D. Osguthorpe, M.N. SAnger, Teaching Morally and Teaching Morality, „Teacher Education Quarterly” 36(2009), nr 3, s. 7-19. 
przejawiają się w konkretnych okolicznościach: najpierw eksplorujemy fakt we wszystkich jego objawach (kto i w jaki sposób postępuje, jak zmienia się zachowanie, uczucia, relacje wskutek tego albo innego działania i in.), potem formułujemy nakazy moralne. Ten sposób poznania wynika z właściwości myślenia dzieci młodszego wieku szkolnego, które według J. Piageta charakteryzuje się logiką indukcyjną. Poznanie rzeczywistości moralnej może mieć formę indywidualną (dziecko-dorosły) oraz grupową - w postaci dyskusji o sytuacjach z życia szkolnego lub pozaszkolnego, których świadkiem było dziecko. Poszukiwanie rozwiązania dylematów moralnych pod kierownictwem dorosłego pogłębia u dzieci świadomość istoty moralności oraz rozwija umiejętność uwzględniania pozycji innych dzieci ${ }^{20}$.

Wspólna obserwacja i wyjaśnienie zachowania, które jest moralnie właściwe lub niewłaściwe, jest także ważnym elementem rozwoju ,ja” idealnego, czyli obrazu tego, jakim dziecko chce być, oraz obrazu tego, jakim ono nie chce zostać. Należy podkreślić, że ,ja” idealne pożądane/niepożądane różni się od „ja” idealnego powinnościowego, którego podstawą jest poczucie obowiązku, jakby z zewnątrz narzuconego. Na treść obrazu ,ja” idealnego składają się obrazy konkretnych postaci, które są atrakcyjne dla dziecka, oraz postaci, które są nieprzyjazne dla niego. Takimi wzorami mogą stać się realni ludzie (nauczyciel, starsze rodzeństwo, rówieśnicy i in.) lub bohaterzy z książek (filmów). Między czytaniem literatury pięknej a oglądaniem filmów zachodzą istotne psychologiczne różnice. Wiadomo, że to, co dzieje się na ekranie, dziecko w omawianym okresie wiekowym odbiera raczej emocjonalnie niż rozsądnie: atrakcyjny bohater wchodzi w duszę dziecka bezpośrednio, gdy jego zdolności umysłowe pozostają jeszcze bardzo ograniczone, żeby świadomie oceniać zachowanie tego bohatera, często dość kontrowersyjnego. Pamiętajmy, że emocjonalnie nasycone filmy nie potrzebują działalności świadomej.

Czytanie książek i zrozumienie przeczytanego tekstu, które intensywnie rozwija się w młodszym wieku szkolnym pod kierownictwem dorosłego, pozwala połączyć atrakcyjność ze świadomością. W trakcie czytania dziecko przekształca tekst w obrazy. W pewnym sensie dziecko tworzy w wyobraźni swój film, na co potrzebuje czasu, rozważania o przyczynach i skutkach zachowania bohaterów, oceniania ich działań, wynikiem czego staje się bardziej świadoma ocena bohaterów jako atrakcyjnych lub nieatrakcyjnych. Kiedy dziecko mówi „Moimi ulubionymi bohaterami są...” lub „Nie lubię tego bohatera”, to może wskazywać na jego moralne wzory. W związku z tym wychowawca musi celowo poszukiwać wśród literatury pięknej tekstów, które zawierają w sobie moralne dylematy

20

D. Lapsley, P. Stey, Moral Self-Identity as the Aim of Education, s. 84-100. 
i przeciwległe sposoby ich rozwiązywania. Oczywiście teksty te muszą być ciekawe i zrozumiałe dla dzieci. Duży potencjał rozwojowy mają opowieści, w których zachowanie bohaterów zmienia się od moralnie niewłaściwego do moralnie pożądanego, co wskazuje dziecku drogę do samodoskonalenia.

Wraz z przekazywaniem wiedzy o moralności wychowawcy skupiają się na kształceniu zachowania odpowiadającego normom moralnym. Można wyodrębnić co najmniej trzy podstawowe idee, które są w potocznym rozumieniu i które pozostają dość szeroko wdrażane w praktyce wychowania. Pierwsza idea to „nauczanie przez modelowanie", została ona przedmiotem analizy naukowej w ramach teorii społecznego uczenia się A. Bandury. Kładzie nacisk na charakterystyki modelu do naśladowania. Koncepcja ta ujawnia się w praktyce wychowania w zwracaniu uwagi dzieci na dobre i złe przykłady zachowania innych ludzi, co uwarunkuje raczej rozwój rozumienia moralności niż zachowania. Ukryta idea naśladowania powoduje także zwiększoną kontrolę komunikacji dziecka (poszukiwanie dobrego przyjaciela). Akcentujemy tutaj konieczność moralnego samodoskonalenia wychowawców (teaching morally), na które wskazują w swoich pracach G. Fenstermacher [i in.] i K. Rizzo [i in. ${ }^{21}$.

Druga idea bazuje na założeniu, że aktywność własna podmiotu jest meryk torycznym czynnikiem rozwoju osobowości. Idea ta w szerokim rozumieniu przejawia się w zaangażowaniu dzieci w czynności pomocowe, altruistyczne w środowisku rodzinnym i szkolnym oraz w działalności wolontariackiej. Ciekawie, że L. Kohlberg, który jest znanym twórcą teorii rozumowania moralnego, zauważył, że włączenie uczniów w działania altruistyczne zwiększa poziom ich rozwoju moralnego ${ }^{22}$. Liczne badania potwierdzają te zależności, ale w ślad za D. Narvaez i D. Lapsle należy mieć na uwadze to, że te praktyki są konieczne, ale nie są dostateczne do wykształcenia moralności ${ }^{23}$.

Trzecia idea dotycząca sposobów kształcenia zachowania moralnego wynika z praktyki stosowania kar i nagród jako narzędzi, za pomocą których dorośli wstrzymują zachowanie niepożądane oraz wspierają działania pożądane. Bez wchodzenia w dyskusję na temat istoty i skuteczności tych metod, ale wracając do rozpowszechnionej praktyki, można z dość wielkim prawdopodobieństwem

${ }^{21}$ G.D. Fenstermacher, R.D. Osguthorpe, M.N. SAnger, Teaching Morally and Teaching Morality, s. 7-19. K. Rizzo, M. BAJovic, Moral Literacy Through Two Lenses: Pre-service Teachers, „International Journal of Teaching and Learning in Higher Education” 28(2016), nr 1, s. 131-138.

22 T. DAwson, Moral Education, https://www.researchgate.net/publication/254789360 (dostęp: 28.02.2018).

23 D. Narvaez, D.K. Lapsley, Teaching Moral Character: Two Alternatives for Teacher Education, „The Teacher Educator” 43(2008), nr 2, s. 156-172. 
stwierdzić, że rodzaje kar i nagród, dotyczących czynności o charakterze moralnym, mało się różnią od kar i nagród stosowanych do innych zachowań dzieci.

Prawdziwa moralność potrzebuje rozwoju umiejętności dokonywania samodzielnego wyboru na podstawie świadomie przyjętych norm i zasad moralnych, co nie dokonuje się za pomocą potocznie stosowanych kar i nagród czy naśladowania dobrym przykładem. Wychowawca musi wiedzieć, że moralnie pożądane czy niepożądane zachowanie jest następstwem funkcjonowania wewnętrznych struktur psychicznych, połączonych między sobą w całość. Nauczyciele i rodzice spotykają się z tą całością „twarzą w twarz” w konkretnych sytuacjach, potrzebujących natychmiastowego reagowania.

Uporządkowanie licznych sytuacji o charakterze moralnym, które na pierwszy rzut oka są dość różnorodne, pozwala bardziej świadomie podejść do oddziaływań wychowawczych oraz uwzględnić ich potencjał rozwojowy. Niezależnie od konkretnych norm moralnych wszystkie sytuacje można podzielić według kilku kryteriów. Po pierwsze według kryterium podmiotowości i przedmiotowości istnieją sytuacje, w których dziecko jest sprawcą (podmiotem) czynu moralnego, oraz takie, w których dziecko jest odbiorcą (przedmiotem) działania moralnego lub niemoralnego. Po drugie, należy uwzględnić, że są sytuacje, w których dzieci zachowują się w sposób moralnie pożądany oraz sytuacje z zachowaniem moralnie niepożądanym. Po trzecie, należy rozróżnić sytuacje, gdy wychowawca ma możliwość wpływać na proces dokonania wyboru moralnego, oraz sytuacje, gdy wychowawca spotyka się z konsekwencjami czynności o charakterze moralnym.

Zastosowanie tych kryteriów pozwala wyodrębnić następujące sytuacje: (1) dziecko jest podmiotem czynu moralnego: 1.1 dziecko postępuje moralnie (podzieliło się z rodzeństwem, ofiarowało zabawki, okazało wsparcie rówieśnikowi $\mathrm{i}$ in.). Proces dokonania wyboru oraz jego skutki są widoczne dla dorosłego; 1.2 dziecko przekracza normę moralną (np. mówiło nieprawdę, wzięło zabawkę bez pytania właściciela o zgodę). Wychowawca zwykle spotka się z konsekwencjami niewłaściwego zachowania; (2) dziecko jest przedmiotem czynu moralnego: 2.1 dziecko cierpi wskutek niemoralnego zachowania rówieśnika (stało się ofiarą dokuczania, krzywdy i in.); 2.2 inny postępuje wobec dziecka zgodnie z normami moralności.

Każda wskazana sytuacja może zostać opisana z uwzględnieniem specyficznych celów i oddziaływań wychowawczych, wynikających z właściwości rozwoju moralności dzieci młodszego wieku szkolnego.

Podejście wychowawcze do pierwszego rodzaju sytuacji (dziecko jest podmiotem) zależy od tego, czy sytuacja potrzebuje pewnej czynności według normy moralnej (pomoc, ofiarowanie), czy dziecko należy powstrzymywać w zachowaniu przekraczającym normę. W ramach określonego rozumienia 
natury moralności najważniejszym celem wychowawczym w tych warunkach jest rozwój umiejętności samodzielnego dokonania wyboru między dwoma sprzecznymi tendencjami motywacyjnymi. Sytuacje wychowawcze, gdy drugi człowiek jest w potrzebie, mogą zostać zaplanowane przez dorosłego (działalność wolontariacka) lub pojawiają się jako nieoczekiwane (ktoś potrzebuje pomocy). W tych warunkach zadaniem wychowawcy będzie z jednej strony - odwracanie uwagi dziecka od istniejącej w tej chwili aktywności, która może być nasycona emocjonalnie (gry, hobby, zabawy z przyjaciółmi), a z drugiej - uwidocznienie trudności drugiego człowieka i wspieranie u dziecka chęci do pomocy. Sytuacje, w których dziecko stoi przed wyborem: przekraczać normę, czy nie - w tym okresie są zwykle ukryte przed dorosłym, w związku z czym okazują się niedostępne do oddziaływań wychowawczych. Oprócz tego niepożądane zachowanie wynika często z emocjonalnie intensywnych przeżyć, z którymi dzieciom bardzo trudno radzić sobie. Wychowawca w podobnych warunkach spotyka się już z konsekwencjami niewłaściwego zachowania dzieci. Celem wychowawczym jest tu kształcenie umiejętności refleksji nad swoim postępowaniem oraz wprowadzenie w życie dziecka sposobów pokonywania przykrych skutków zachowania, które nie odpowiada normie moralnej. Należy podkreślić, że dorośli nie muszą oceniać zachowania dziecka, lecz sprzyjać rozwojowi procesów samooceniania. Uznanie przez dziecko swojego czynu za niewłaściwy jest trudne. Wychowawca w tych okolicznościach zwraca się do znaczących wzorów, z którymi dziecko się identyfikuje (obraz ,ja” idealne) i które służą jako wzory odniesienia. Ten proces ułatwia zapewnianie dziecka, że jest ono dobre i potrafi zachowywać się według normy. Uświadomienie dziecku, że jest ono w całości dobre, ale jego konkretne działanie okazało się złe - wywołuje konflikt w obrazie ,ja”. Drogą rozwiązania tego konfliktu jest rezygnacja z obrazu siebie jako sprawcy złego działania oraz dążenie do wykonywania moralnie pożądanych czynności (Jakobson, 1984). Pobudzenie dziecka do samoanalizy w konkretnych okolicznościach przekraczania normy sprzyja rozwojowi tożsamości moralnej jako merytorycznego elementu mechanizmu dokonania wyboru moralnego. Wychowawca może także pomóc dziecku w poszukiwaniu sposobów wyeliminowania konsekwencji amoralnego zachowania (prosić o przebaczenie, naprawić uszkodzony przedmiot, skompensować szkody).

Konsekwencje sytuacji postępowania moralnego też zasługują na uwagę ze strony dorosłego. Celem wychowawczym staje się kształcenie obrazu ,ja” dziecka jako sprawcy (podmiotu) moralnego działania. Wiadomo, że obraz ,ja” w młodszym wieku szkolnym odzwierciedla konkretne aspekty zachowania dziecka oraz jest wynikiem utożsamienia się ze swoimi czynami i ich skutkami. We wskazanych sytuacjach dorosły współtowarzyszy procesom rozwoju moralnej 
tożsamości w następujący sposób: podkreśla, że konkretne zachowanie dziecka jest cenne dla innych ludzi i dla współdziałania (wskazanie na pozytywne konsekwencje), akcentuje pożądane cechy dziecka (,jesteś pomocny”) oraz mówi o swoich uczuciach, związanych z jego postępowaniem (,jestem dumny”). To wszystko wzmacnia poczucie własnej podmiotowości dziecka i utrwala jego moralną tożsamość (,jestem pomocny”).

W drugim rodzaju sytuacji dziecko znajduje się w pozycji biernej, będąc osobą, do której zostało skierowane działanie moralne lub niemoralne. Celem wychowawczym w tych sytuacjach jest rozwój świadomości dziecka odnośnie do własnych przeżyć związanych z postępowaniem moralnym lub niemoralnym drugiego człowieka oraz kształcenie umiejętności wyrażenia wdzięczności za wsparcie i umiejętności radzenia sobie z poczuciem urazy. Uczestnictwo dorosłego w podobnych sytuacjach jest skierowane na rozwój kompetencji emocjonalnych, rozumowania w dziedzinie moralności, a także umiejętności podziękowania oraz przebaczania.

\section{ZAKOŃCZENIE}

Przegląd istniejących badań dotyczących rozwoju moralności w młodszym wieku szkolnym daje wskazówki, jak podchodzić do kształcenia u dzieci poznania rzeczywistości moralnej, tożsamości moralnej i innych struktur psychicznych, które zapewniają postępy w rozpatrywanym obszarze. Ta wiedza może wyglądać z pozycji wychowawców jako mozaika, którą trudno dopasować do konkretnych sytuacji lub jakaś część tej wiedzy staje się wartościową samą w sobie bez uwzględnienia innych charakterystyk samoregulacji moralnej. Całościowe ujmowanie funkcjonowania moralności pozwala oznaczyć dwie kategorie oddziaływań wychowawczych. Po pierwsze, są to oddziaływania skierowane na kształcenie każdego z wydzielonych elementów systemu samoregulacji moralnej (wiedza moralna, tożsamość moralna, oceny moralne, empatia i in.), które można rozpatrywać jako przygotowanie dzieci do spotkania z realnymi sytuacjami o charakterze moralnym. Druga kategoria oddziaływań odnosi się do konkretnych sytuacji o charakterze moralnym, gdy dziecko jest podmiotem lub przedmiotem czynności moralnych, a dorośli muszą reagować na te sytuacje tu i teraz czy kształtować warunki, które sprzyjają rozwojowi moralności dzieci. W tych sytuacjach odrębne oddziaływania należy połączyć między sobą w całość. Charakter połączenia jest uwarunkowany właściwościami konkretnej sytuacji, co zostało omówione wyżej. 
Podjęte rozważania teoretyczne o sytuacjach wychowawczych można traktować jako próbę wprowadzania istniejącej wiedzy o rozwoju moralności dzieci w młodszym wieku szkolnym w realne procesy wychowania moralnego. Oczywiście, rozpoczęte kształtowanie myśli teoretycznej o oddziaływaniach wychowawczych w realnych sytuacjach potrzebuje weryfikacji empirycznej oraz metod i sposobów wychowania moralności dzieci w młodszym wieku szkolnym.

\section{LITERATURA}

Borzowicz L.I., Problemy formirowanija licznosti. Moskwa: Wydawnictwo Instituta prakticzeskoj psychologii 1997.

Burns P., Razwitie Ja-koncepcji i wospitanie, Moskwa: Wydawnictwo Progress 1986.

Chutorański M., Moralność, rozwój moralny, wychowanie moralne, „Teraźniejszość - Człowiek - Edukacja” 2012, nr 2, s. 97-106.

Dawson T., Moral Education: A Review of Constructivist Theory and Research, unpublished position paper, Berkeley, CA: University of California at Berkeley 1994, https://www.researchgate.net/publication/254789360 (dostęp: 28.02.2018).

DAwydow W.W., Problemy razwiwajuszego obuczenia, Moskwa: Wydawnictwo Pedagogika 1986.

Drobnicki O.G., Poniatie morali, Moskwa: Wydawnictwo Nauka 1974.

Fenstermacher G.D., Osguthorpe R.D., Sanger M.N., Teaching Morally and Teaching Morality, „Teacher Education Quarterly” 36(2009), nr 3, s. 7-19.

Foa C., Brugman D., Mancinia T., School Moral Atmosphere and Normative Orientation to Explain Aggressive and Transgressive Behaviours at Secondary School, „Journal of Moral Education" 41(2012), nr 1, s. 1-22.

James W., Pragmatyzm. Nowoje nazwanie dla niekotorych starych metodow myszlenia. Popularnyie lekcii po filosofi, Moskwa: Wydawnictwo ЛКИ 2011.

Jambon M., Smetana J., Moral Complexity in Middle Childhood: Children's Evaluations of Necessary Harm, „Developmental Psychology” 50(2014), nr 1, s. 22-33.

Hardy S., Walker L.J, Olsen J.A., Woodbury R.D., Hickman J.R., Moral Identity as Moral Ideal Self: Links to Adolescent Outcomes, „Developmental Psychology” 50(2014), nr 1, s. 45-57.

Harter S., Developmental Processes in the Construction of the Self, w: Integrative Processes and Socialization: Early to Middle Childhood, red. T.D. Yawkey, J.E. Johnson, Hillsdale, NJ: Lawrence Erlbaum Associates 1988, s. 45-78.

Harter S., The Construction of the Self: Developmental and Sociocultural Foundations, New York-London: Guilford 2012.

Kochanska G., Koenig J.L., Barry R.A., Sanghang K., Yoon J.E., Children's Conscience during Toddler and Preschool Years, Moral Self, and a Competent, Adaptive Developmental Trajectory, „Developmental Psychology” 46(2010), s. 1320-1332.

Lapsley D., Stey P., Moral Self-Identity as the Aim of Education, w: Handbook of Moral and Character Education, red. L. Nucci and D. Narvaez, London: Taylor \& Francis, 2014, s. 84-100.

Leea Chi-M., TAYlor M.J., Moral Education Trends over 40 Years: A Content Analysis of the Journal of Moral Education (1971-2011), „Journal of Moral Education” 42(2013), nr 4, s. 399-429.

Narvaez D., Lapsley D.K., Teaching Moral Character: Two Alternatives for Teacher Education, „The Teacher Educator” 43(2008), nr 2, s. 156-172. 
Nucci L., Turiel E., Capturing the Complexity of Moral Development and Education, „Mind, Brain, and Education" 3(2009), nr 3, s. 151-159.

Rizzo K., Bajovic M., Moral Literacy through Two Lenses: Pre-service Teachers, „International Journal of Teaching and Learning in Higher Education” 28(2016), nr 1, s. 131-138.

\section{PSYCHOLOGICZNE UWARUNKOWANIA WYCHOWANIA MORALNEGO DZIECI W MŁODSZYM WIEKU SZKOLNYM}

\section{Streszczenie}

Celem artykułu jest usystematyzowanie teoretycznych i empirycznych danych, dotyczących psychologicznych uwarunkowań wychowania moralności dzieci w młodszym wieku szkolnym. Zakłada się, że moralność ujawnia się w sytuacjach, gdy należy uwzględniać potrzeby i prawa drugiego człowieka, i występuje jako system samoregulacji dokonania wyboru między zachoj waniem moralnie pożądanym a zachowaniem przekraczającym normę moralną. Każdy etap rozwoju dziecka został scharakteryzowany specyficznymi społecznymi interakcjami, warunkującymi kształtowanie pewnych struktur samoregulacji moralnej. Nowe warunki życia szkolnego powodują pogłębienie poznania rzeczywistości moralnej oraz wpływają na rozwój tożsamości moralnej. Zgodnie z wymienionymi właściwościami rozwoju moralności zostały wyodrębnione merytoryczne aspekty całościowego procesu wychowania w młodszym wieku szkolnym. Po pierwsze są to oddziaływania skierowane na kształcenie każdego z wydzielonych elementów systemu samoregulacji moralnej (wiedza moralna, tożsamość moralna, oceny moralne, empatia $i$ in.). Druga kategoria oddziaływań odnosi się do realnych sytuacji, gdy dziecko jest podmiotem lub przedmiotem czynności moralnych. Właściwości sytuacji o charakterze moralnym uwarunkują cele wychowawcze oraz system oddziaływań skierowane na wspieranie rozwoju moralności dzieci.

Słowa kluczowe: moralność; rozwój moralności; młodszy wiek szkolny; wychowanie moralności. 